\title{
Effect of feed supplementation on chemical composition of meat of three genotypes of scavenging ducklings in coastal areas of Bangladesh
}

\author{
MM Rahman ${ }^{1}$, MJ Khan ${ }^{* 2}$, SD Chowdhury ${ }^{3}$ \\ ${ }^{1}$ Department of Livestock Services, Sopura, Rajshahi; ${ }^{2}$ Department of Animal Nutrition; ${ }^{3}$ Department of Poultry \\ Science, Bangladesh Agricultural University, Mymensingh 2202, Bangladesh
}

\begin{abstract}
The present study was conducted to evaluate the chemical composition of three genotypes of scavenging ducklings (Muscovy, Pekin and Desi White) in coastal areas of Bangladesh. Three ducks from each genotype were slaughtered at 6,10 and $14^{\text {th }}$ week of age. The results indicated that dry matter yield was highest in Muscovy (40.91 and 44.40) followed by Pekin (39.30 and 44.31) and Desi White (35.67 and 41.82) for control and supplemental group, respectively at $14^{\text {th }}$ week of age. The concentration of crude protein was highest in Muscovy (18.76 and 19.90), intermediate in Pekin (18.40 and 19.66) and the lowest in Desi White (17.20 and 19.14) for two feeding regimes at $14^{\text {th }}$ week of age. The ether extract content varied from 17.21 to 23.16. Genotype and feed showed significant effect $(p<0.01)$ on crude protein and ether extract content of duck meat at 10 and $14^{\text {th }}$ week of age. The ash content was highest in Muscovy followed by Pekin and Desi White throughout the experimental period. Genotypes, feed and interaction between genotypes and feed showed no significant $(p>0.05)$ effect on ash content at $14^{\text {th }}$ week of age. Genotypes and feed showed significant effect $(p<0.01)$ but the interaction between genotype and feed had no significant effect $(p>0.05)$ on DM and moisture content of duck meat.
\end{abstract}

\begin{tabular}{l}
\hline Key words: Chemical composition, coastal region, duck \\
\hline Bangladesh Animal Husbandry Association. All rights reserved. $\quad$ Bang. J. Anim. Sci. 2014. 43 (1): 25-29
\end{tabular}

\section{Introduction}

Rural poultry production, particularly chickens, followed by duck production, plays a significant role in the socio-economic development of Bangladesh. Almost $90 \%$ of all rural families keep a small number of indigenous chicken and duck under traditional free range semi-scavenging system. The contribution of scavenging fowls and ducks in terms of supplying meat and eggs is still believed to be large in Bangladesh poultry production, which eventually can be considered as an indispensable mechanism and vehicle to promote the rural economy. The genotypes of ducks raised commonly in coastal areas are Muscovy, Pekin and Desi. There are many advantages of duck production and duck can be considered as a good all purpose bird. Now a days duck production has contributed a considerable amount of income of households in coastal region of Bangladesh. Compared to large livestock species, ducks grow fast, have a short life cycle and produce a high number offspring
(Dong 1999). Manipulation of carcass composition is achieved by genetic, dietary and environmental factors. Dietary factors, including feed restriction, dietary energy and protein contents and dietary fiber can change carcass characteristics particularly carcass fat. There is a great potentiality to improve the productivity of ducks in these areas through better utilization of available local feedstuffs and better management practices under scavenging system. Limited investigations have been made on the chemical composition of meat-type ducks reared under scavenging system. But no investigations have yet been taken to evaluate the chemical composition of meat of ducks at different feeding regime and age reared in coastal areas of Bangladesh under rural condition. So, the present study was undertaken to know the effect of feed supplementation on chemical composition of meat of three duck genotypes reared in coastal areas of Bangladesh. 


\section{Supplementation effect on duck meat quality}

\section{Materials and Methods}

The experiment was conducted at three villages viz. Noakhali Mouza, Ewazbalia and Karomullah of Noakhali district in Bangladesh for a period of 98 days. A total of one hundred and seventy four day-old ducklings of three genotypes (Muscovy, Pekin and Desi White) were collected from Central Duck Breeding Farm, Narayangonj, Dhaka and assigned at random in a 2 (feeding regimes) $\times 3$ (genotypes) factorial experiment in a Randomized Block Design having 3 replicates in each treatment. Each replicate consisted of 7, 10 and 12 ducklings for Muscovy, Pekin and Desi White, respectively. The birds of control group received feed only from scavenging and the birds of supplemented group received mash feed in addition to normal scavenging.

Ducklings were brooded for 2 weeks and at the age of 15 days all the ducklings were handed over to the farmers. A bamboo house of $0.14 \mathrm{~m}^{2}$ floor space for each bird was also supplied to the farmers. All ducklings were vaccinated against duck plague and duck cholera. The experimental birds were allowed to scavenge freely in the agricultural fields, ponds and ditches near to farmer's house for 9 hours (8.00 A.M to 5.00 P.M). In addition to scavenging feed, the birds belonging to supplemented group received a concentrate mixture composed of $50 \%$ rice polish, $30 \%$ broken rice and $20 \%$ wheat bran in the form of wet mash. Supplemental feeds were given @ $10 \mathrm{~g}$ in the first week which was further increased @ $10 \mathrm{~g}$ in each week until 8 weeks. Clean drinking water was also supplied in bowls in each time of feeding. Proper care and managemental practices were followed by the farmers throughout the experimental periods.

Sampling was done three times during the experimental period. The first time at 6 weeks of age, the second time at 10 weeks of age and the third time at 14 weeks of age. A total of 54 ducklings were randomly collected from each village for slaughtering in order to get meat sample.

Ducks were slaughtered at 6,10 and 14 weeks of age to study the chemical composition. At each time, 3 birds from each genotype were randomly slaughtered at 2, 4 and 6 hours of scavenging following "halal" method by severing the jugular vein and allowed to bleed completely (Singh et al. 2003). A total of $300 \mathrm{~g}$ meat sample from each bird was collected and kept in a freezer for chemical analysis. The meat was sliced and minced by mincing machine.

Samples of meat were subjected to chemical analysis for the determination of dry matter $(D M)$, crude protein $(C P)$, ether extract (EE) and ash following the methods of AOAC (2004). Data collected and calculated for different variables were subjected to analysis of variance in accordance with the procedures of $2 \times 3$ factorial experiment in a Randomized Block Design (Steel et al. 1997) using a MSTAT-C statistical package.

\section{Results and Discussion}

\section{Dry matter (DM)}

It is revealed from the study that there was a variation in dry matter content of meat among genotypes which ranged from 33.69 to 39.16 on $6^{\text {th }}$ week, 35.04 to 42.30 on $10^{\text {th }}$ week and 35.67 to 44.40 on $14^{\text {th }}$ week irrespective of feeding regimes. In this experiment the highest dry matter content of meat was found in Muscovy (44.40) followed by Pekin (44.31) and Desi White (41.82) at $14^{\text {th }}$ week of age for supplemental group. On the contrary, dry matter content of meat for Muscovy, Pekin and Desi White was $40.91,39.30$ and 35.67, respectively for ducks reared only by scavenging giving no supplemental diet. The highest dry matter content of Muscovy meat (44.40) was very close to the values reported by Zhou et al. (2001) and the value was slightly lower than the values reported by Farrell et al. (1981) who found 49\% DM in meat content. The dry matter content of meat sample in this study at 6 weeks of age irrespective of genotypes and feeding regimes was higher than the values as reported by Zhou et al. (2000). Similar trend of results were also found at $10^{\text {th }}$ and $14^{\text {th }}$ week of age which was supported by Mazanowsky (2003), Zhou et al. (2000 and 2001) and Baeza et al. (2002). The DM found in this experiment at 14 weeks of age was higher than the findings of Haque (2003). It was also demonstrated from the Table 1 that increased trend of DM content with the increase live weight regardless of genotypes found 
coincide with Haque (2003), Zhou et al. (2000) and Baeza et al. (2002). Genotype and feed showed significant effect $(p<0.01)$ on DM content but genotype and feed interaction had no significant effect $(p>0.05)$ on DM content.

\section{Crude protein (CP)}

The crude protein (CP) content of meat of different genotypes of ducklings varied from 17.20 to 20.98 for control and supplemented group. The CP content of meat sample found in this experiment was very close to the values reported by Mazanowsky et al. (2003), Baeza et al. (2002), Khalifa and Nassar (2001). The protein content decreased with increasing age was supported by Haque (2003). The reported value of $\mathrm{CP}$ content in this study was slightly higher than the values as reported by Zhou et al. (2000 and 2001) and Farrell (2000). Farrell (2000) in an experiment reported that there was a significant effect $(p<0.01)$ of diet on carcass protein. This observation is closely associated with the present findings. Genotype and feed showed significant $(p<0.01)$ effect on $C P$ content at $10^{\text {th }}$ and $14^{\text {th }}$ week of age but the interaction between genotype and feed at $6^{\text {th }}$ and $14^{\text {th }}$ week of age did not show significant $(p>0.05)$ effect on $\mathrm{CP}$ content of meat.

\section{Ether extract (EE)}

The EE of meat sample among genotypes ranged from 14.37 to 17.31 for $6^{\text {th }}$ week, 15.24 to 23.63 for $10^{\text {th }}$ week and 17.21 to 26.36 for $14^{\text {th }}$ week of age irrespective of feeding regimes. The highest EE of meat sample was found in Pekin (26.36) followed by Muscovy (23.16) and Desi White (21.38) at $14^{\text {th }}$ week of age for supplemental group. Similar trend of EE of meat sample was found in Pekin (21.28) followed by Muscovy (19.26) and Desi White (17.21) for the same period reared without any feed supplementation. The EE content of meat sample found in this experiment was well agreement with the findings of Baeza et al. (2002), Farrell (2000) and Zhou et al. (2001) but slightly higher than the values reported by Mazanowsky et al. (2003). Farrell (2000) showed that there was significant effect $(p<0.01)$ of diet on carcass fat. This observation is closely associated with the present findings. The increased fat content with the increase of age was supported by Haque (2003).

Table 1. Chemical composition of meat of three genotypes of ducklings at 6,10 and 14 weeks of age

\begin{tabular}{|c|c|c|c|c|c|c|c|c|c|c|}
\hline \multirow{3}{*}{ Parameters } & \multirow{3}{*}{$\begin{array}{l}\text { Age in } \\
\text { weeks }\end{array}$} & \multicolumn{6}{|c|}{ Genotypes } & \multirow{2}{*}{\multicolumn{3}{|c|}{ SED and level of significance }} \\
\hline & & \multicolumn{2}{|c|}{ Muscovy } & \multicolumn{2}{|c|}{ Pekin } & \multicolumn{2}{|c|}{ Desi White } & & & \\
\hline & & Control & Suppl. & Control & Suppl. & Control & Suppl. & Genotype (G) & $\begin{array}{l}\text { Feed } \\
(F)\end{array}$ & $G \times F$ \\
\hline \multirow{3}{*}{$\begin{array}{l}\text { DM } \\
\text { (g/100g sample) }\end{array}$} & 6 & $36.71^{c}$ & $39.16^{a}$ & $36.46^{c}$ & $34.48^{a b}$ & $33.69^{d}$ & $37.36^{b c}$ & $0.51^{\text {** }}$ & $0.42^{* *}$ & $0.73^{\mathrm{NS}}$ \\
\hline & 10 & $38.85^{c}$ & $42.30^{a}$ & $38.63^{c}$ & $42.17^{\mathrm{a}}$ & $35.04^{d}$ & $40.21^{b}$ & $0.34^{\star *}$ & $0.28^{\star \star}$ & $0.49 \mathrm{NS}$ \\
\hline & 14 & $40.91^{b}$ & $44.40 \mathrm{a}$ & $39.30 \mathrm{a}$ & $44.31^{\mathrm{a}}$ & $35.67 d$ & $41.82^{b}$ & $0.49^{* \star}$ & $0.40^{* *}$ & $0.69 \mathrm{NS}$ \\
\hline \multirow{3}{*}{$\begin{array}{l}\text { CP } \\
(g / 100 g D M)\end{array}$} & 6 & $20.22^{c}$ & $20.98^{a}$ & $20.03^{c}$ & $20.87^{a b}$ & $19.76^{c}$ & $20.47 \mathrm{abc}$ & $0.25 \mathrm{NS}$ & $0.20^{* \star}$ & $0.36^{\mathrm{NS}}$ \\
\hline & 10 & $19.63^{a}$ & $20.26^{a}$ & $18.57^{b}$ & $20.05^{a}$ & $17.25^{c}$ & $19.76^{a}$ & $0.26^{* *}$ & $0.21^{* *}$ & $0.37^{\star}$ \\
\hline & 14 & $18.76^{\mathrm{cd}}$ & $19.90^{a}$ & $18.40^{\mathrm{b}}$ & $19.66^{a b}$ & $17.20^{e}$ & $19.14^{\mathrm{bc}}$ & $0.22^{\star *}$ & $0.18^{\star *}$ & $0.32^{\mathrm{NS}}$ \\
\hline \multirow{3}{*}{$\begin{array}{l}\text { EE } \\
(g / 100 g \text { DM) }\end{array}$} & 6 & $15.27^{c}$ & $16.39^{b}$ & $15.78^{b c}$ & $17.31^{a}$ & $14.37^{d}$ & $15.85^{b c}$ & $0.24^{* *}$ & $0.19^{* *}$ & $0.34^{\mathrm{NS}}$ \\
\hline & 10 & $17.78^{d}$ & $20.74^{b}$ & $19.11^{c}$ & $23.63^{a}$ & $15.24 \mathrm{e}$ & $19.17^{c}$ & $0.19^{\star *}$ & $0.16^{* *}$ & $0.27^{\star}$ \\
\hline & 14 & $19.26^{d}$ & $23.16^{b}$ & $21.28^{c}$ & $26.36^{a}$ & $17.21 \mathrm{e}$ & $21.38^{c}$ & $0.24^{\star *}$ & $0.20^{\star *}$ & $0,35^{\mathrm{NS}}$ \\
\hline \multirow{3}{*}{$\begin{array}{l}\text { Ash } \\
\text { (g/100g DM) }\end{array}$} & 6 & $2.97^{a b}$ & $3.11^{a}$ & $2.90^{\mathrm{b}}$ & $2.99 \mathrm{ab}$ & $2.88^{b}$ & $2.95^{b}$ & $0.05^{\mathrm{NS}}$ & $0.04^{*}$ & $0.07 \mathrm{NS}$ \\
\hline & 10 & $3.22^{\mathrm{bc}}$ & $3.30^{a}$ & $3.17^{c}$ & $3.28 \mathrm{ab}$ & $3.15^{c}$ & $3.25^{\mathrm{ab}}$ & $0.03^{\mathrm{NS}}$ & $0.02^{\star}$ & $0.04^{\star}$ \\
\hline & 14 & 3.28 & 3.36 & 3.23 & 3.30 & 3.20 & 3.27 & $0.04^{\mathrm{NS}}$ & $0.03^{\mathrm{NS}}$ & $0.05^{\mathrm{NS}}$ \\
\hline \multirow{3}{*}{$\begin{array}{l}\text { Moisture } \\
\text { (g/100g DM) }\end{array}$} & 6 & $63.29 \mathrm{~b}$ & $60.84^{b}$ & $63.54 \mathrm{~b}$ & $61.52^{b}$ & $66.31^{b}$ & $62.64^{b}$ & $0.92^{\mathrm{NS}}$ & $0.75^{\star \star}$ & $1.30 \mathrm{NS}$ \\
\hline & 10 & $61.15^{b}$ & $57.70^{d}$ & $61.37^{b}$ & $57.83^{\mathrm{cb}}$ & $64.96^{a}$ & $59.79 b c$ & $0.72^{* *}$ & $0.59^{* \star}$ & $1.02^{\mathrm{NS}}$ \\
\hline & 14 & $59.09 c$ & $55.6^{d}$ & $60.70^{\mathrm{b}}$ & $55.69 d$ & $64.33^{a}$ & $58.18^{c}$ & $0.48^{\star *}$ & $0.39^{* *}$ & $1.60^{\mathrm{NS}}$ \\
\hline
\end{tabular}

$D M$, dry matter; $C P$, crude protein; $E E$, ether extract; Figures with different superscripts in a row differ significantly; $*, p<0.05, * *, p<0.01 ; N S$, non-significant 


\section{Supplementation effect on duck meat quality}

Ash

The ash content of meat sample among genotypes ranged from 2.88 to 3.36 throughout the experimental period irrespective of feeding regimes. It was also revealed from the study that the highest ash content of meat sample was found in Muscovy (3.36) followed by Pekin (3.30) and Desi White $(3.27)$ at $14^{\text {th }}$ week of age for supplemental group and similar trend was also observed with ducks of control group. The reported value of ash content in this study was higher than values as reported by Baeza et al. (2002) and Zhou et al. (2000) but slightly lower than the values reported by Ukil (1992). Khalifa and Nassar (2001) reported an ash content of 1.0 to $1.4 \%$ in ducks, which was much lower than that obtained in the current study. Genotype, feed and interaction between genotype and feed did not show any significant effect $(p>0.05)$ on ash content of meat sample at $14^{\text {th }}$ week of age.

\section{Conclusion}

The results indicated that the chemical composition of meat of three genotypes of scavenging ducklings fed on supplemental diets were significantly $(p>0.01)$ higher than those reared by scavenging. The dry matter as well as crude protein, ether extract and total ash content of meat sample was highest in Muscovy as compared with Pekin and Desi White. The results also demonstrated that higher fat and lower protein indicating a significant effect of genotype and to some extent differences in carcass composition within a genotype could be explained by diet combination. Further investigation is needed for analysis of amino acid and cholesterol content in meat sample of Muscovy, Pekin and Desi White ducks reared in coastal region in order to have good quality and hygienically safe meat for human consumption.

\section{References}

AOAC (Association of the Official Agricultural Chemists) (2004). Official Methods of Analysis. Washington DC, P. 1-34.

Baeza EC, Dessay N, Wacrenier G, Marche G, Listrat A (2002). Effect of selection for improved body weight and composition on muscle and meat characteristics in
Muscovy duck. British Poultry Science, 43 560-568.

Baeza E, De Carville H, Salichon M, Marche G, Leclercq B (1997). Effects of selection, over three and four generation, on meat yield and fatness in Muscovy ducks. British Poultry Science, 38: 359-365.

Baeza E, Salichon MR, Marche G, Wacrenier N, Dominguez B, Culioli J (2000). Effects of age and sex on the structural, chemical and technological characteristics of mule duck meat. British Poultry Science, 41: 300-307.

Dong NTK (1999). Studies on the performance of growing ducks fed brewery waste in the Mekong Delta. M.Sc. Thesis. Swedish University of Agricultural Sciences.

Farrell DJ (2000). Meat-type ducks-Self selection of diets. A report for the Rural Industries Research and Development Corporation, School of Land and Food Sciences, The University of Queensland, 7-14.

Farrell DJ, Atmamihardja SI, Hood RL (1981). A note on the effects of heat stress on carcass composition and adipose tissue cellularity of ducklings. British Poultry Science, 26: 533-536.

Haque MM (2003). Meat yield, proximate composition and cholesterol content in meat of different poultry species according to weight and sex. MS Thesis, Department of Poultry Science, Bangladesh Agricultural University, Mymensingh.

Khalifa AH, Nassar AM (2001). Nutritional and bacteriological properties of some game duck carcasses. Nahrung, 45: 286-292.

Mazanowski A, Kisiel T, Gornowicz E (2003). Carcass quality, meat traits and chemical composition of meat in ducks of paternal strains A44 and A55. Animal Science Papers and Reports, 21: 251-263.

Olver MD (1997). Effect of sweet lupins on duckling growth. British Poultry Science, 38: 115-117.

Singh PK, Khatta VK, Thakur RS, Dey S, Sangwan ML (2003). Effects of phytase supplementation on the performance of broiler chickens fed maize and wheat based diets with different levels of non-phytate phosphorus. Asian-Australasian Journal of Animal Sciences, 16: 1642-1649. 
Rahman et al. (2014) Bang. J. Anim. Sci. 43 (1): 25- 29

Steel RGD, Torrie JH, Dickey DA (1997). Principles and procedure of statistics-A Biometrical Approach. $3^{\text {rd }}$ ed. McGraw-Hill Co., Inc., New York and London. P. 139177.

Ukil MA (1992). Availability of nutrients to scavenging chickens and ducks in Bangladesh. MSc Thesis. Department of Poultry Science, Bangladesh Agricultural University, Mymensingh.
Zhou CH, Ohtani S, Tanaka KI (2000). Carcass composition, parts proportion and fat deposition of meat-type growing ducks. J apanese Poultry Science, 37: 357-364.

Zhou CH, Ohtani S, Tanaka KI (2001). Effect of dietary energy and protein levels on growth, body composition and fatty acid synthesis in fattening period of meat-type ducks. Japanese Poultry Science, 38: 5865. 